\title{
Pengaruh Project Based Learning (PJBL) Model Terhadap Penguasaan Konsep Fisika Pada Siswa Kelas X SMA Negeri 1 Kota Bengkulu
}

\author{
Yulia Monika, Afrizal Mayub, Andik Purwanto \\ Program studi Pendidikan Fisika FKIP-UNIB \\ Email: yuliamonikaa@gmail.com
}

\begin{abstract}
ABSTRAK
Penelitian bertujuan untuk mengetahui pengaruh pembelajaran PJBL (Project Based Learning) terhadap penguasaan konsep fisika peserta didik dan mengetahui respon peserta didik terhadap pembelajaran PJBL (Project Based Learning ).Penelitian Eksperimen ini dengan subjek penelitian seluruh siswa kelas X IPA 5 yang berjumlah 26 orang. Hasil penelitian ini menunjukan bahwa pada pertemuan pertama nilai rata-rata hasil tes awal siswa sebesar 38,84 dan nilai tes akhir siswa sebesar 85. Terdapat peningkatan nilai siswa dari rata-rata nilai tes awal siswa semula 38,84 menjadi rataratanya sebesar 85 pada nilai tes akhirnya. Pada pertemuan kedua kedua didapatkan nilai rata-rata tes awal siswa sebesar 38,84 dan nilai rata-rata tes akhir sebesar 83,84 disini terlihat peningkatan nilai siswa dari rata-rata nilai tes awal siswa semula 38,84 menjadi rata-ratanya sebesar 83,84 pada nilai tes akhirnya. Pada pertemuan ketiga dan didapatkan nilai rata-rata tes awal siswa yaitu sebesar 42,30 Setelah melakukan pembelajaran berbasis proyek maka siswa diberikan tes akhir dan didapatkan nilai tes akhir siswa yaitu sebesar 85,38. Berdasarkan hasil penelitian dapat disimpulkan bahwa pembelajaran berbasis proyek (Project Based Learning) berpengaruh terhadap penguasaan konsep fisika dan respon siswa di kelas X SMA Negeri 1 Kota Bengkulu.
\end{abstract}

Kata kunci : Model Pembelajaran Project Based Learning, Lembar Kerja Peserta Didik, Penguasaan Konsep Fisika Siswa dan Respon Siswa

\begin{abstract}
This research is to know the influence of learning PJBL (Project Based Learning) on the mastery of physics concept learners and Know the response of learners to learning PJBL (Project Based Learning). The subjects of this study are all students of class X IPA 5 which amounted to 26 people. The results of this study showed that obtained at the first meeting the average score of the initial test results of students amounted to 38.84 and the final test score of 85 students and seen increase in student scores from the average initial test score of 38.84 students to be an average of 85 on the final test score. In the second second meeting, the average score of the students 'initial test is 38.84 and the average score of the final test is 83.84 , it can be seen that the students' grade increase from the average initial test score of 38.84 students to the average is 83,84 at the final test score. At the third meeting and obtained the average score of the initial test of students that is equal to 42.30 After doing ProjectBased Learning then the students are given the final test and obtained the final test score of 85.38 students. Based on the results of research can be concluded that Project Based Learning (Project Based Learning) influence on the mastery of physics concepts and student responses in class X SMA Negeri 1 Kota Bengkulu.
\end{abstract}

Keywords: Learning Based Project Model, Student's Worksheet, Mastery of Student Physics Concept and Student Response.

\section{PENDAHULUAN}

Fisika merupakan salah satu cabang ilmu pengetahuan alam (IPA) yang mendasari perkembangan teknologi dan konsep hidup harmonis dengan alam. Fisika juga merupakan ilmu yang mempelajari tentang materi dan zat yang meliputi sifat komposisi, perubahan dan energi yang dihasilkan. Oleh karena itu, perkembangan ilmu pengetahuan dan teknologi yang sangat pesat saat ini tidak lepas dari ilmu Fisika sebagai salah satu ilmu dasar.

Pada hakikatnya IPA merupakan kumpulan pengetahuan, cara berfikir dan penyelidikan. IPA tersebut sebagai pengetahuan karena berupa fakta, konsep, prinsip, hukum, teori dan model. Fisika juga dipandang sebagai suatu proses dan sekaligus produk sehingga dalam pembelajaranya harus mempertimbangkan strategi atau metode pembelajaran yang 
efektif dan efisien yaitu salah satunya melalui kegiatan praktik. Hal ini dikarenakan melalui kegiatan praktik,siswa melakukan olah pikir dan juga olah tangan.

Belajar adalah suatu proses yang ditandai dengan adanya perubahan pada diri seseorang. Perubahan sebagai hasil dari proses belajar dapat ditunjukan dalam berbagai bentuk seperti perubahan pengetahuan, penguasaan, sikap dan tingkah laku, keterampilan, kecakapan, kebiasaan, serta perubahan aspek-aspek lain yang ada pada individu yang belajar. Sebagian besar masyarakat menggap belajar di sekolah adalah usaha penguasaan materi ilmu pengetahuan.

Salah satu faktor yang menjadi penyebab kurangnya penguasaan konsep Fisika siswa terhadap materi yang diajarkan adalah kurangnya keterlibatan siswa saat kegiatan pembelajaran. Selain itu, guru bidang studi fisika yang mengajar di kelas yang menjadi subjek penelitian cendrung hanya menerapkan satu bentuk model pembelajaran, yaitu model pembelajaran langsung.

Maka dari itu penggunaan strategi pembelajaran yang tidak tepat akan sangat mempengaruhi proses pengalaman belajar yang dialami siswa. Untuk itu, dibutuhkan strategi yang memperhatikan kebutuhan dan keinginan siswa, sehingga tercipta suasana belajar yang lebih menarik dan bermakna yang mampu meningkatkan kualitas belajar dan penguasaan siswa terhadap materi-materi yang disampaikan.

Dalam penelitian ini, setelah melakukan observasi awal di kelas $\mathrm{X}$ dan wawancara langsung kepada guru bidang studi Fisika SMA N 1 Kota Bengkulu. Peneliti masih banyak menemukan permasalahan dalam proses pembelajaran Fisika yang berlangsung. Kendala dan permasalahan tersebut berupa masih kurangnya penguasaan konsep Fisika siswa terhadap materi yang diajarkan dan siswa yang kurang aktif saat kegiatan pembelajaran. Selain itu, guru bidang studi fisika yang mengajar di kelas yang menjadi subjek penelitian cendrung hanya menerapkan satu bentuk model pembelajaran, yaitu model pembelajaran langsung.

Permasalahan-permasalahan tersebut, haruslah dicarikan solusinya sehingga dapat membuat pembelajaran fisika menjadi lebih menarik dan bermakna, yang tidak hanya dapat meningkatkan hasil belajar siswa, namun juga penguasaan konsep yang baik dan bertahan lama di dalam memori peserta didik. Salah satu solusi tersebut adalah dengan melihat adanya pengaruh pembelajaran PJBL (Project Based Learning) Model yang beranggapan bahwa metode pembelajaran ini adalah metode yang menggunakan proyek/kegiatan sebagai media.

Dalam pembelajaran PJBL (Project Based Learning Mode) tugas guru adalah memberikan pertanyaan esensial, yaitu pertanyaan yang dapat memberikan penugasan peserta didik dalam melakukan suatu. Melalui penelitian ini, diharapkan mampu menjadi salah satu strategi alternatif bagi guru dalam pembelajaran fisika sehingga tercipta suasana belajar yang lebih produktif dan bermakna.

Berdasarkan hasil wawancara dengan guru mata pelajaran fisika di SMA N 1 Kota Bengkulu, model pembelajaran Project Based Learning ini belum pernah diterapkan dikarenakan kepada siswa di SMA N 1 Kota Bengkulu tetapi dikarenakan besarnya biaya yang dikeluarkan untuk melakukan pembelajaran dengan menggunakan model ini serta memerlukan waktu yang lama untuk penerapannya. Untuk mengetahui pengaruh Project Based Learning Model terhadap penguasaaan konsep siswa kelas X SMA N 1 Kota Bengkulu, saya ingin mengadakan penelitian "Pengaruh Project Based Learning (PJBL) Model Terhadap Penguasaan Konsep Fisika Pada Siswa Kelas X SMA Negeri 1 Kota Bengkulu”. Adapun penelitian ini bertujuan untuk mengetahui pengaruh pembelajaran PJBL (Project Based Learning Model) terhadap penguasaan konsep fisika siswa kelas X SMA N 1 Kota Bengkulu dan Mengetahui respon siswa terhadap pembelajaran PJBL (Project Based Learning Model) pada konsep fisika siswa kelas X SMA N 1 Kota Bengkulu.

\section{METODE PENELITIAN}

Penelitian yang dilaksanakan adalah penelitian Quasi Experimental dengan desain yang digunakan adalah One Group Pretest Posttest Design. Penelitian ini tidak menggunakan kelas 
pembanding namun menggunakan tes awal (Pretest) dan dan tes akhir (Posttest). Subjek penelitian ini adalah siswa kelas X IPA 5 SMA N 1 Kota Bengkulu Tahun Ajaran 2017/2018 yang berjumlah 26 orang (9 siswa laki-laki dan 17 siswa perempuan). Teknik pengumpulan data diperoleh dengan tes tertulis yang di ujikan pada tes awal dan tes akhir. Tes awal diberikan untuk mengetahui kemampuan awal siswa tentang materi usaha dan energi sebelum diberikan perlakuan berupa pembelajaran berbasis proyek. Tes awal dan tes akhir menggunakan perangkat tes yang sama. Sedangkan untuk mengetahui respon belajar siswa dengan menggunakan Angket respon siswa.

\subsection{Teknik Analisis Data}

\subsubsection{Uji Validitas}

Validitas adalah ukuran yang menunjukan tingkat-tingkat kevalidan atau kesahihan data sesuai instrumen. Suatu instrumen yang valid atau shahih mempunyai validitas tinggi. Sebaliknya, instrumen yang kurang valid berarti memiliki validitas rendah.

Sebuah instrumen dikatakan valid apabila mampu mengukur apa yang diinginkan. Sebuah instrumen dikatakan valid apabila dapat mengungkapkan data dari variabel yang diteliti secara tepat. Tinggi rendahnya validitas menunjukan sejauh mana data yang terkumpul tidak menyimpang dari gambaran validitas yang dimaksud.

Untuk memperoleh nilai yang valid maka digunakan rumus Korelasi Product Momen sebagai berikut:

$$
\mathrm{r}_{\mathrm{xy}}=\frac{\Sigma x y}{\sqrt{\left(\Sigma X^{2}\right)\left(\Sigma Y^{2}\right)}}
$$

Dengan angka besar :

$$
\mathrm{r}_{\mathrm{xy}}=\frac{n(\Sigma x y)-(\Sigma X)(\Sigma Y)}{\sqrt{(N} \Sigma X^{2}-\left(\Sigma X^{2}\right)\left(N \Sigma Y^{2}-\left(\Sigma Y^{2}\right)\right)}
$$

\subsection{Uji Normalitas}

(Arikunto, 2014)

Analisis ini bertujuan untuk mengetahui data yang digunakan berdistribusi normal. Rumus yang digunakan untuk menguji kenormalan data ini adalah dengan Chi-Kuadrat.

$$
X^{2}=\sum_{i=1}^{k} \frac{\left(O_{i}-E_{i}\right)^{2}}{E_{I}}
$$

Keterangan :

$X^{2}$ : Chi Kuadrat

$\mathrm{O}_{\mathrm{i}}$ : Frekuensi Hasil Pengamatan

$\mathrm{E}_{\mathrm{i}}$ : Frekuensi Harapan

$\mathrm{K}$ : Banyak Kelas Interval

Kriteria : Tolak $\mathrm{H}_{0}$ jika $\mathrm{H}_{0}$ jika $X^{2}{ }_{\text {hitung }} \geq X^{2}$ tabel atau $X^{2}$ dengan taraf signifikasi $5 \%$ Dalam hal ini hal lainnya $\mathrm{H}_{0}$ diterima artinya yang diuji berdistribusi normal.

Kriteria : Tolak $\mathrm{H}_{0}$ jika $X^{2}$ hitung $\geq X^{2}$ tabel atau $X^{2}$ dengan taraf signifikasi $5 \%$ Dalam hal ini hal lainnya $\mathrm{H}_{0}$ diterima artinya yang diuji berdistribusi normal.

\subsection{Uji Hipotesis}

Hipotesis dalam penelitian ini adalah adanya pengaruh penggunaan model pembelajaran berbasis proyek (Project Based Learning Model) terhadap respon belajar siswa dan penguasaan konsep fisika siswa.

Dalam penelitian ini menggunakan One Sample T-Test Method, yang merupakan uji hipotesis Untuk sampel tunggal.

Hipotesis Statistiknya :

$\mathrm{H}_{0}: \mu=\mu_{0}$

$\mathrm{H}_{1}: \mu \neq \mu_{0}$

Statistik uji :

$$
t=\frac{x-\mu_{0}}{\frac{s}{\sqrt{n}}}
$$


keterangan :

$\mathrm{t}=$ Nilai $\mathrm{t}$ yang dihitung,disebut $\mathrm{t}$ hitung

$x=x$ rata-rata

$\mu_{0}=$ Nilai yang dihipotesiskan

$\mathrm{s}$ = Simpangan baku

$\mathrm{n}=$ Jumlah anggota sampel

\subsection{Pengujian Effect Size}

Dalam penelitian in untuk mengetahui pengaruh Project Based Learning Model dalam pembelajaran digunakan persamaan Effect Size yang dirumuskan oleh Cohen D :

$d=\frac{(\text { Spost })-(\text { Spre })}{\text { opooled }}$

opooled $=\frac{\sqrt{\left(\sigma_{\text {pre+ }}^{2} \sigma_{\text {post }}^{2}\right)}}{2}$

Persamaan ini dirumuskan untuk melihat ukuran pengaruh setelah diberikan perlakuan sehingga dibutuhkan nilai rata-rata $\left(S_{\text {pre }}\right)$ dan nilai rata-rata kelas setelah diberikan perlakuan $\left(S_{\text {post }}\right)$. Untuk mengetahui nilai d juga dibutuhkan standar deviasi sebelum dilakukan perlakuan ( $\sigma p r e)$ dan standar deviasi setelah diberikan perlakuan ( $\sigma p o s t$ ). Pengkatagorian ukuran pengaruh terhadap peningkatan penguasaan konsep menggunakan Effect Size adalah sebagai berikut.

Tabel 1. Kriteria Nilai Effect Size (d)

\begin{tabular}{|c|c|}
\hline Nilai d & Interprestasi \\
\hline $0 \leq 0,20$ & Lemah \\
\hline $0,21 \leq 0,5 \leq 0,79$ & Sedang \\
\hline $0,80 \leq$ & Kuat \\
\hline
\end{tabular}

(Rahmaniar, Suhandi, \& Sari, 2015)

III. HASIL DAN PEMBAHASAN

\subsection{Penguasaan Konsep Siswa}

Penguasaan konsep adalah kemampuan siswa berupa penguasaan sejumlah materi pelajaran dimana siswa tidak sekedar mengetahui atau mengingat konsep yang dipelajari, tetapi mampu mengungkapkan kembali dalam bentuk lain yang mudah dimengerti, memberikan interpretasi data, dan mampu mengaplikasikan konsep sesuai dengan struktur kognitifnya.

Djarwanto (2001) menyatakan bahwa kurva suatu distribusi frekuensi dapat berbentuk simetris atau tidak simetris (menceng atau condong). Distribusi yang tidak simetris atau menceng sebelah kiri dinamakan sknewness positif atau skew kanan). Hal ini berarti, sebagian besar siswa tersebut memiliki nilai rata-rata relatif rendah seperti yang terlihat pada gambar 1 dan nilai rata-rata siswa relatif tinggi terlihat pada gambar 2 pada nilai posttest siswa.

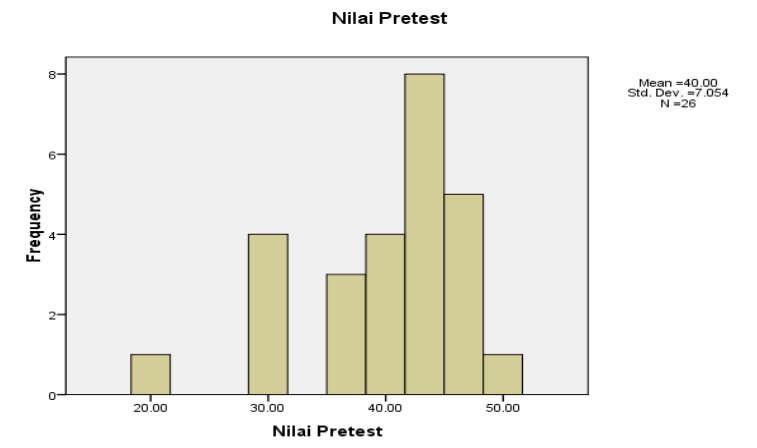

Gambar 1. Histogram Distribusi Frekuensi Nilai Rata-Rata Pretest 


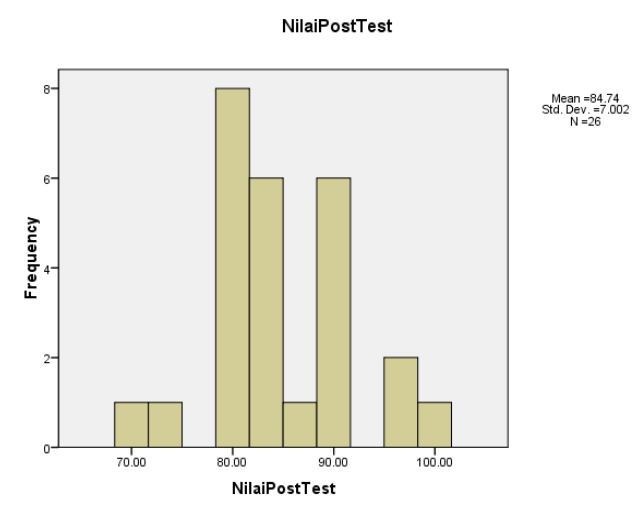

\section{Gambar 2. Histogram Distribusi Frekuensi Nilai Rata-Rata Posttest}

Pertemuan I didapatkan pada pertemuan pertama nilai rata-rata pretest siswa sebesar 38,84 dan nilai posttest siswa sebesar 85 dan disini terlihat peningkatan nilai siswa dari ratarata nilai pretest semula 38,84 menjadi rata-ratanya sebesar 85 pada nilai posttest. Pertemuan II pada pertemuan kedua didapatkan nilai rata-rata pretest siswa sebesar 38,84 dan nilai ratarata posttestnya sebesar 83,84 disini terlihat peningkatan nilai siswa dari rata-rata nilai pretest semula 38,84 menjadi rata-ratanya sebesar 83,84 pada nilai posttest. Pertemuan III didapatkan nilai rata-rata pretest siswa yaitu sebesar 42,30 . Setelah melakukan pembelajaran berbasis proyek maka siswa diberikan posttest dan didapatkan nilai posttest siswa yaitu sebesar 85,38 dan disini terlihat peningkatan kemampuan penguasaan konsep siswa yang terlihat pada nilai posttest siswa yang meningkat.

Penelitian antara pembelajaran yang menggunakan pembelajaran Project Based Learning terhadap nilai pretest dan posttest siswa memiliki hasil nilai rata-rata posttest lebih tinggi dibandingkan nilai rata-rata pretes. Pada penelitian yang dilakukan hanya menggunakan satu kelas yaitu kelas X IPA 5 terlihat bahwa rata-rata nilai pretest siswa yaitu sebesar 40 dan terlihat pada rata-rata nilai posttest siswa yaitu meningkat sebesar 84,74 dan disini terlihat nilai siswa meningkat dengan adanya penerapan pembelajaran berbasis proyek.

\subsection{Respon siswa}

Setelah pembelajaran berakhir siswa diberikan angket tentang pembelajaran berbasis proyek yang diikuti peserta didik sejumlah 26 siswa. Adapun respon siswa terhadap kegiatan pembelajaran berbasis proyek yaitu digambarkan seperti tabel 2 :

Tabel 2 Tabulasi Perasaan Senang dan Tidak Senang

\begin{tabular}{l|l|l|l}
\hline No & \multicolumn{1}{|c|}{ Uraian Senang } & Tidak Senang \\
\hline 1. & $\begin{array}{l}\text { Bagaimana perasaan anda } \\
\text { selama mengikuti kegiatan pembelajaran } \\
\text { ini? }\end{array}$ & $100 \%$ & - \\
\hline 2. & $\begin{array}{l}\text { Bagaimana perasaan anda terhadap materi } \\
\text { pembelajaran }\end{array}$ & $95,4 \%$ & $4,6 \%$ \\
\hline 3. & $\begin{array}{l}\text { Bagaimana perasaan anda terhadap } \\
\text { suasana pelajaran dikelas }\end{array}$ & $95,4 \%$ & $4,6 \%$ \\
\hline 4. & $\begin{array}{l}\text { Bagaimana perasaa anda terhadap cara } \\
\text { penyajian materi oleh guru }\end{array}$ & $95,4 \%$ & $4,6 \%$ \\
\hline 5. & $\begin{array}{l}\text { Bagaimana tanggapan anda jika pokok } \\
\text { bahasan selanjutnya menggunakan } \\
\text { pembelajaran seperti ini ? }\end{array}$ & - \\
\hline
\end{tabular}

Berdasarkan tabel 2 hakekatnya bahwa, persentase rata-rata siswa yang merasa senang terhadap pembelajaran berbasis proyek sebesar 95,4\% sedangkan persentase rata-rata siswa yang merasa tidak senang sebesar $4,6 \%$.

Besar persentase siswa yang merasa senang tersebut disebabkan pembelajaran berbasis proyek tidak membosankan, dan lebih mudah untuk memahami materi yang disampaikan. 


\section{SIMPULAN DAN SARAN \\ 4.1 Simpulan}

Berdasarkan hasil analisis data penelitian dan pembahasan dapat ditarik kesimpulan bahwa : terdapat pengaruh positif pembelajaran fisika dengan menggunakan pembelajaran Project Based Learning Model (PJBL) terhadap penguasaan konsep siswa kelas X SMA N 1 Kota Bengkulu dengan adanya peningkatan nilai pretest siswa yang meningkat setelah diberikan perlakuan pembelajaran berbasis proyek, yang terlihat pada peningkatan nilai postetst siswa yang meningkat secara signifikan.Respon siswa pada pembelajaran menggunakan model pembelajaran berbasis proyek ini memiliki respon yang baik hal ini terlihat dari alasan siswa menjawab senang jika pokok bahasan selanjutnya menggunakan model pembelajaran berbasis proyek karena mereka tidak merasa bosan selama proses pembelajaran berlangsung. Alasan mereka mengatakan senang karena mudah untuk memahami materi yang disampaikan

\subsection{Saran}

Bagi guru,guru dapat menerapkan sistem pembelajaran berbasis proyek ini memberikam pengaruh yang positif terhadap respon dan penguasaan konsep fisika siswa.Penelitian lanjut dengan menggunakan pembelajaran Project Based Learning(PJBL) adalah utamakan kegiatan-kegiatan yang mendorong siswa untuk lebih aktif pada saat pembelajaran berlangsung.

\section{DAFTAR PUSTAKA}

Arikunto, S. (2014). Prosedur Penelitian suatu pendekatan praktik. Jakarta: Rineka Cipta.

Rahmaniar, A., Suhandi, A., \& Sari, M. (2015). Ukuran Pengaruh Pendekatan Interactive Conceptual Intruction pada pembelajaran Fisika untuk Meningkatkan Pemahaman Konsep Usaha dan Energi Siswa SMA.

Sadiman, A., Raharjo, Haryono, A., \& Rahardjito. (2010). Media Pendidikan. Jakarta: PT Raja Grafindo Persada. 